\title{
Genome-wide analysis of DNA methylation in tongue squamous cell carcinoma
}

\author{
SHENG ZHANG ${ }^{1}$, XIANG-LING FENG $^{2}$, LEI SHI $^{3}$, CHAO-JIAN GONG ${ }^{1}$, \\ ZHI-JING HE ${ }^{1}$, HAN-JIANG WU ${ }^{1}$ and TIAN-YOU LING ${ }^{1}$ \\ ${ }^{1}$ Department of Oral and Maxillofacial Surgery, the Second Xiangya Hospital, Central South University, \\ Changsha, Hunan 410011; ${ }^{2}$ Cancer Research Institute, Xiangya School of Medicine, \\ Central South University, Changsha, Hunan $410008 ;{ }^{3}$ Department of Pathology, the Second \\ Xiangya Hospital, Central South University, Changsha, Hunan 410011, P.R. China
}

Received December 29, 2012; Accepted January 23, 2013

DOI: 10.3892/or.2013.2309

\begin{abstract}
Tongue squamous cell carcinoma (TSCC) is one of the most common types of oral cancer; however, its molecular mechanisms remain unclear. In this study, methylated DNA immunoprecipitation (MeDIP) coupled with methylation microarray analysis was performed to screen for aberrantly methylated genes in adjacent normal control and TSCC tissues from 9 patients. Roche NimbleGen Human DNA Methylation 385K Promoter Plus CpG Island Arrays were used to detect 28,226 CpG sites. A total of 1,269 hypermethylated $\mathrm{CpG}$ sites covering 330 genes and 1,385 hypomethylated $\mathrm{CpG}$ sites covering 321 genes were found in TSCC tissue, compared to the adjacent normal tissue. Furthermore, we chose three candidate genes (FBLN1, ITIH5 and RUNX3) and validated the DNA methylation status by methylation-specific PCR (MS-PCR) and the mRNA expression levels by reverse transcription PCR (RT-PCR). In TSCC tissue, FBLN1 and ITIH5 were shown to be hypermethylated and their expression was found to be decreased, and $R U N X 3$ was shown to be hypomethylated, however, its mRNA expression was found to be increased. In addition, another three genes (BCL2L14, CDCPI and DIRAS3) were tested by RT-PCR. In TSCC tissue, BCL2L14 and $C D C P 1$ expressions were markedly upregulated, and DIRAS3 expression was significantly downregulated. Our data demonstrated that aberrant DNA methylation is observed in TSCC tissue and plays an important role in the tumorigenesis, development and progression of TSCC.
\end{abstract}

Correspondence to: Dr Sheng Zhang, Department of Oral and Maxillofacial Surgery, the Second Xiangya Hospital, Central South University, 139 Middle Renmin Road, Changsha, Hunan 410011, P.R. China

E-mail: ddszhangsh@gmail.com

Key words: tongue squamous cell carcinoma, DNA methylation, $\mathrm{CpG}$ island, microarray, biomarker

\section{Introduction}

Oral cancer accounts for $2-4 \%$ of all cancer cases worldwide (1). An estimated 263,900 new cases and 128,000 deaths from oral cancer occurred globally in 2008 (2). More than $90 \%$ of all oral cancer cases are oral squamous cell carcinomas (OSCCs), which are a result of multistep processes that develop from the combined effects of a patient's genetic predisposition and exposure to environmental influences, including tobacco, alcohol, betel quid, chronic inflammation and viral infection (3). Tongue squamous cell carcinoma (TSCC) is a common OSCC. Imaging systems and treatment strategies in TSCC are improving substantially, however, 5-year survival statistics remain low. The molecular mechanisms underlying its clinical characteristics including carcinogenesis, development, progression, invasion, and metastasis have yet to be fully elucidated. Epigenetics studies recently showed that aberrant DNA methylation is involved in the progress of TSCC (4). DNA methylation is an important regulator of gene transcription and its role in carcinogenesis and development has been a topic of considerable interest in recent years. DNA methylation, which represses transcription of the promoter region of tumor suppressor genes leading to gene silencing, has been studied extensively (5).

DNA methylation is a very stable epigenetic mark and next generation sequencing studies have shown that several genes are aberrantly methylated in various types of cancer $(6,7)$. Tissue specific DNA methylation patterns are stabilized during embryonic development, and are maintained through cell divisions. Aberrant DNA methylation patterns have been associated with a large number of human malignancies and are found in two distinct forms: hypermethylation and hypomethylation (8). The majority of DNA methylation studies focus on the analysis of $\mathrm{CpG}$ islands located in the promoter areas of candidate genes. However, differentially methylated areas may be located within genes and at large distances from the nearest neighboring genes (9). In the past decade, researchers focused only on a few candidate genes of DNA methylation in TSCC-related genes $(4,5,10)$. Nevertheless, systematic studies on the genome-wide distribution of methylated loci in TSCC 
Table I. List of primers of methylated (M) and unmethylated (U) sequences for MS-PCR analysis.

\begin{tabular}{|c|c|c|}
\hline Gene & Primer & Sequence \\
\hline \multirow[t]{4}{*}{ FBLN1 } & M primer & F: 5'-ATTAGGAGATTCGCGGTTTC-3' \\
\hline & & R: 5'-GCTCCATAAACGACGAACG-3' \\
\hline & U primer & F: 5'-GATTAGGAGATTTGTGGTTTTG-3' \\
\hline & & R: 5'-CACACTCCATAAACAACAAACA-3' \\
\hline \multirow[t]{4}{*}{ ITIH5 } & M primer & F: 5'-TTGGCGATAGAAATTAAGTAAGTTC-3' \\
\hline & & R: 5'-AACCACCTATATTAACCCACG-3' \\
\hline & U primer & F: 5'-TTGGTGATAGAAATTAAGTAAGTTTGT-3' \\
\hline & & R: 5'-AAAACCACCTATATTAACCCCACA-3' \\
\hline \multirow[t]{4}{*}{$R U N X 3$} & M primer & F: 5'-TTACGAGGGGCGGTCGTACGCGGG-3' \\
\hline & & R: 5'-AAAACGACCGACGCGAACGCCTCC-3' \\
\hline & U primer & F: 5'-TTATGAGGGGTGGTTGTATGTGGG-3' \\
\hline & & R: 5'-AAAACAACCAACACAAACACCTCC-3' \\
\hline
\end{tabular}

remain scarce. With the advent of next generation sequencing, genome-wide screening has become an attractive and useful tool for profiling TSCC.

In this study, methylated DNA immunoprecipitation (MeDIP) in combination with microarray-based hybridization was performed in adjacent normal control and tumor tissues from 9 patients with TSCC (11). Extensive DNA methylation distribution information from human TSCC and its adjacent normal tissues provided a preliminary genomic DNA methylation profile. Selected differentially expressed genes were further validated using methylation-specific PCR (MS-PCR) and reverse transcription PCR (RT-PCR).

\section{Materials and methods}

Patients and samples. Samples were obtained from 20 patients diagnosed with TSCC who underwent surgery at the Second Xiangya Hospital of Central South University and the Hunan Provincial Tumor Hospital. The study protocol was approved by the Ethics Committees of Central South University and written informed consent was obtained from all patients. None of the patients were given adjuvant chemotherapy or radiation prior to the operation. For each TSCC case, fresh samples were obtained from the primary tumor tissue and the adjacent normal tongue mucosa with a clear surgical margin to tumor. Surgical margins were considered as tumor-free or negative at least $5 \mathrm{~mm}$ of histologically normal tissue according to the pathological examination. The samples were snap frozen in liquid nitrogen and stored at $-80^{\circ} \mathrm{C}$ until subsequent analyses.

MeDIP and methylation microarray hybridization. Genomic DNA from TSCC and adjacent normal control tissue $(n=9)$ were extracted and purified according to the DNeasy Blood and Tissue kit (Qiagen, Germantown, MD, USA). Then, DNA samples were pooled to one pair and sheared by sonication to obtain fragments between 400 and 500 bp and were immunoprecipitated by anti-5-methylcytidine antibody according to the MagMeDIP kit (Diagenode, Liège, Belgium). Fully methylated DNA was obtained by whole-genome amplification using the GenomePlex ${ }^{\circledR}$ Whole Genome Amplification kit (Sigma-Aldrich, St. Louis, MO, USA). MeDIP DNA and input DNA were labeled with Cy5 and Cy3, respectively, and then analyzed using Human DNA Methylation 385K Promoter Plus CpG Island Arrays (Roche NimbleGen, Madison, WI, USA), which were used to detect 28,226 CpG sites. Gene chips were scanned by GenePix 4000B microarray scanner and hybridization signals were analyzed using GenePix Pro 6.0 hybridization analysis software. Probe-rich value setting was $\geq 2.0$.

$M S$-PCR analysis. To determine the methylation status of the three selected genes (FBLN1, ITIH5 and RUNX3), we used MS-PCR in 20 pairs of samples from adjacent normal control and TSCC tissues. Genomic DNA was isolated by using Wizard ${ }^{\circledR}$ Genomic DNA Purification kit (Promega, Madison, WI, USA). Complete bisulfite conversion and purification of DNA were performed according to the EpiTect ${ }^{\circledR}$ Bisulfite kit (Qiagen). The fully methylated and fully unmethylated DNA samples were used as controls, and a water blank reaction was used as control for contamination. Following amplification by PCR, products were resolved on $1 \%$ agarose gels containing $0.5 \mu \mathrm{g} / \mathrm{ml}$ ethidium bromide and visualized under UV transillumination. Primers for MS-PCR analysis are shown in Table I.

RT-PCR analysis. To determine the mRNA expression level of the six selected genes (FBLN1, ITIH5, RUNX3, BCL2L14, $C D C P 1$ and DIRAS3), we used RT-PCR in 20 pairs of samples from adjacent normal control and TSCC tissues. Total RNA was isolated from the sample tissues using TRIzol ${ }^{\circledR}$ reagent (Invitrogen, Grand Island, NY, USA) according to the manufacturer's protocol. RNA was efficiently reverse transcribed into cDNA using the Reverse Transcription System (Promega). Primers for RT-PCR analysis and the PCR conditions of the six selected genes are shown in Table II. The expression level of each gene was confirmed by comparison to the expres- 
Table II. List of primers for RT-PCR analysis and the condition of PCR.

\begin{tabular}{|c|c|c|c|c|}
\hline Gene & Primer & $\begin{array}{l}\text { Size of } \\
\text { product (bp) }\end{array}$ & $\begin{array}{c}\text { Annealing } \\
\text { temperature }\left({ }^{\circ} \mathrm{C}\right)\end{array}$ & Cycles \\
\hline FBLN1 & $\begin{array}{l}\text { F: 5'-TCAATACAGTTGCCTAGAGCA-3' } \\
\text { R: 5'-GAGGAACAAGAGGACCCAT-3' }\end{array}$ & 409 & 60 & 28 \\
\hline ITIH5 & $\begin{array}{l}\text { F: 5'-CACAGTTCTCCAGCGACA-3' } \\
\text { R: 5'-CAGGACCGTTTCAGTATCAT-3' }\end{array}$ & 386 & 60 & 32 \\
\hline$R U N X 3$ & $\begin{array}{l}\text { F: 5'-CAGAAGCTGGAGGACCAGAC-3' } \\
\text { R: 5'-TCGGAGAATGGGTTCAGTTC-3' }\end{array}$ & 180 & 62 & 32 \\
\hline BCL2L14 & $\begin{array}{l}\text { F: 5'-TCCAGGTGTCTTTCTAACG-3' } \\
\text { R: 5'-TTGACCTCTGATTCTCCC-3' }\end{array}$ & 407 & 58 & 34 \\
\hline$C D C P 1$ & $\begin{array}{l}\text { F: 5'-CATAAGAGCATCGGTTTAGAG-3' } \\
\text { R: 5'-GGGTAGTTGGCAGACATCA-3' }\end{array}$ & 329 & 58 & 28 \\
\hline DIRAS3 & $\begin{array}{l}\text { F: 5'-TCTCTCCGAGCAGCGCA-3' } \\
\text { R: 5'-CGTCGCCACTCTTGCTGTCG-3' }\end{array}$ & 410 & 62 & 34 \\
\hline$\beta$-actin & $\begin{array}{l}\text { F: 5'-TAAGGAGAAGCTGTGCTACG-3' } \\
\text { R: 5'-GACTCGTCATACTCCTGCTT-3' }\end{array}$ & 459 & 58 & 28 \\
\hline
\end{tabular}
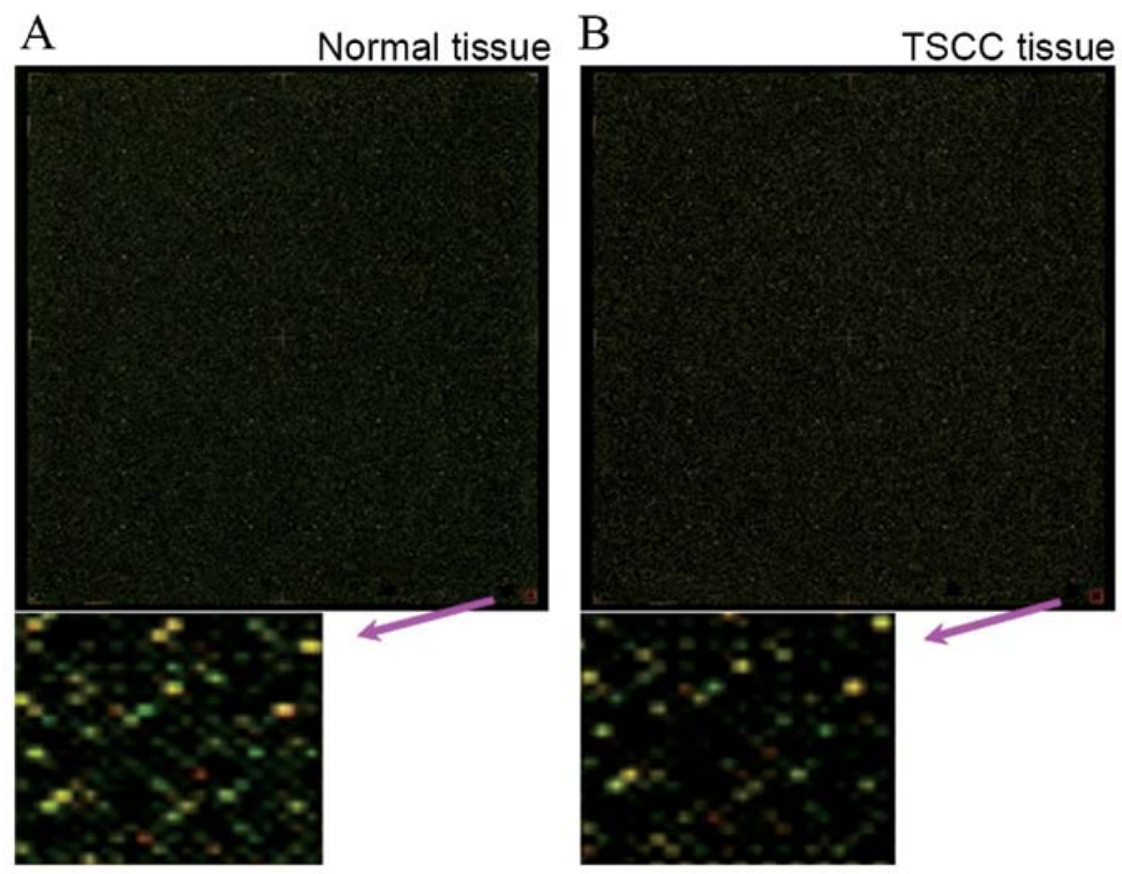

Figure 1. Genome-wide DNA methylation was analyzed from adjacent normal and TSCC tissues, detecting 28,226 CpG sites. The hybridization signals of DNA methylation microarray from nine paired adjacent normal (A) and TSCC (B) tissues are shown.

sion amounts of $\beta$-actin which served as an internal control. Optical density of positive band was subsequently measured using Quantity One 4.62 (Bio-Rad, Hercules, CA, USA).

Statistical analysis. Data are expressed as the means \pm standard deviation (SD). Data were analyzed using SPSS 16.0 (SPSS, Chicago, IL, USA). The results of MS-PCR analysis were analyzed using a two-tailed Fisher exact test. The data of RT-PCR analysis were analyzed using a Student's t test. $P<0.05$ was considered to indicate statistically significant differences.

\section{Results}

Global DNA methylation changes in TSCC tissues. In order to investigate the aberrant genomic DNA methylation in TSCC, we performed methylated DNA amplification coupled with CpG island microarray analysis using a set of TSCC tissue specimens (adjacent normal control tissue vs. tumor tissue) (Fig. 1). Methylation status of the individual 28,226 CpG sites was compared between the 9 pairs of samples. There were 2,654 DNA hypermethylated sites that significantly differed in methy- 
Table III. Frequency of DNA methylation status of three candidate genes in paired adjacent normal and TSCC tissues.

\begin{tabular}{|c|c|c|c|c|c|c|c|}
\hline \multirow[b]{2}{*}{ Group } & \multirow[b]{2}{*}{ Count } & \multicolumn{2}{|c|}{ FBLN1 } & \multicolumn{2}{|c|}{ ITIH5 } & \multicolumn{2}{|c|}{ RUNX3 } \\
\hline & & $\begin{array}{c}\mathrm{U} \\
\mathrm{n}(\%)\end{array}$ & $\begin{array}{c}\mathrm{M} \\
\mathrm{n}(\%)\end{array}$ & $\begin{array}{c}\mathrm{U} \\
\mathrm{n}(\%)\end{array}$ & $\begin{array}{c}\mathrm{M} \\
\mathrm{n}(\%)\end{array}$ & $\begin{array}{c}\mathrm{U} \\
\mathrm{n}(\%)\end{array}$ & $\begin{array}{c}\mathrm{M} \\
\mathrm{n}(\%)\end{array}$ \\
\hline $\mathrm{N}$ & 20 & $16(80 \%)$ & $4(20 \%)$ & $15(75 \%)$ & $5(25 \%)$ & $9(45 \%)$ & $11(55 \%)$ \\
\hline \multirow[t]{2}{*}{$\mathrm{T}$} & 20 & $9(45 \%)$ & $11(55 \%)$ & $6(30 \%)$ & $14(70 \%)$ & $17(85 \%)$ & $3(15 \%)$ \\
\hline & & \multicolumn{2}{|c|}{$\mathrm{P}=0.048^{\mathrm{a}}$} & \multicolumn{2}{|c|}{$\mathrm{P}=0.004^{\mathrm{b}}$} & \multicolumn{2}{|c|}{$\mathrm{P}=0.019^{\mathrm{a}}$} \\
\hline
\end{tabular}

Statistical significance of the difference between the adjacent normal $(\mathrm{N})$ and TSCC $(\mathrm{T})$ tissues was calculated using a two-tailed Fisher exact test. ${ }^{\mathrm{P}} \mathrm{P}<0.05,{ }^{\mathrm{b}} \mathrm{P}<0.01$. U, unmethylated; $\mathrm{M}$, methylated.

lation level between adjacent normal control and TSCC tissue. A total of 1,269 CpG sites covering 330 genes were found to be significantly hypermethylated in TSCC tissues. In our analysis, these genes were located in different chromosomes. Among these hypermethylated genes, 28 genes $(8.48 \%)$ and 27 genes $(8.18 \%)$ were located on chromosome 1 and 19 , respectively. Furthermore, chromosome 17, 16, 7 and 2 had 26 (7.88\%), $24(7.27 \%), 23(6.97 \%)$ and $22(6.67 \%)$ hypermethylated genes, respectively. Chromosome 18 had only 4 hypermethylated genes, accounting for $1.21 \%$. In addition, chromosome 15 or $\mathrm{Y}$ had 5 hypermethylated genes (1.52\%). Of the 330 methylated genes in TSCC, the hypermethylated sites of 218 genes $(66.1 \%)$ were located in the promoter region, $77(23.3 \%)$ in the coding region, and $45(13.6 \%)$ in the downstream of gene, respectively.

In adjacent normal tissue, there were 1,385 hypermethylated $\mathrm{CpG}$ sites, covering 321 genes. Among these genes, up to 40 genes were located on chromosome 19 , accounting for $12.46 \%$. Chromosome $\mathrm{X}$ and 1 had 32 and 23 genes, accounting for 9.97 and $7.17 \%$, respectively. Moreover, chromosome 14 had only 2 genes $(0.62 \%)$. Among the 321 genes, 210 genes $(65.4 \%)$ were located in the promoter region. Familial aggregation was found in these genes of differential methylation. For example, four genes of keratin $(K R T)$ family and three keratin-related proteins $(K R T A P)$ were shown to be hypermethylated in tumor tissue, including KRT 14 and 31 on chromosome 17, KRT 72 and 75 on chromosome 12 , KRTAP10-3 and 10-7 on chomosome 21 and KRTAP2-4 on chromosome 17. Seven members of $M A G E$ (melanoma antigen-encoding gene) family, MAGEA2, MAGEA3, MAGEA4, MAGEA9, MAGEA9B, MAGEA10 and $M A G E A 11$, were found to be hypermethylated in adjacent normal tissue and located on chromosome X.

Validation of aberrantly methylated genes by MS-PCR. To verify the results obtained from our previous DNA methylation microarray study, we selected three candidate genes (FBLN1, ITIH5 and RUNX3), which were based on reports of tumorspecific methylation genes, for further analysis by MS-PCR. Twenty cases of TSCC and paired adjacent tissues were detected by MS-PCR for these three genes. Of these three genes, FBLN1 and ITIH5 were hypermethylated in TSCC tissue, and RUNX3 was hypermethylated in adjacent normal tissue. FBLNI and ITIH5 showed a significantly higher incidence of DNA methylation in TSCC, while RUNX3 had markedly lower incidence of DNA methylation in TSCC than in adjacent normal

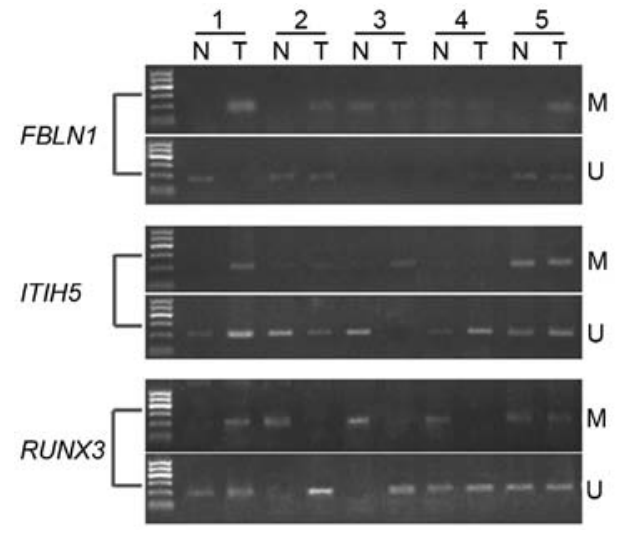

Figure 2. Three candidate genes (FBLN1, ITIH5 and RUNX3) were validated by MS-PCR. Representative bands of MS-PCR using primers of methylated $(\mathrm{M})$ and unmethylated $(\mathrm{U})$ sequences are shown in paired adjacent normal $(\mathrm{N})$ and TSCC $(\mathrm{T})$ tissues.

tissue. As shown in Fig. 2 and Table III, FBLN1 showed DNA methylation in $11 / 20$ cases $(55 \%)$ in TSCC and in $4 / 20$ cases $(20 \%)$ in adjacent normal tissue $(\mathrm{P}=0.048<0.05)$. Moreover, methylation of ITIH5 was detected in 14/20 cases in TSCC and in 5/20 cases in adjacent control tissues, of which the incidence was 70 and $25 \%$, respectively $(\mathrm{P}=0.004<0.01)$. In addition, we observed that $11 / 20$ cases $(55 \%)$ in adjacent normal tissues and only $3 / 20$ cases $(15 \%)$ in TSCC showed DNA methylation of RUNX3 $(\mathrm{P}=0.019<0.05)$. Differences in DNA methylation status of these three genes were statistically significant between adjacent normal and TSCC tissue. These findings were consistent with the microarray study.

Analysis of mRNA expression level of candidate genes by $R T$-PCR. According to our microarray analysis data, we selected six genes, which were highly related to tumorigenesis and development of TSCC, to detect their mRNA expression in the 20 paired samples. These genes included FBLN1, ITIH5, RUNX3, BCL2L14, CDCPI and DIRAS3. As compared with adjacent normal tissue, TSCC tissue showed markedly upregulated expression levels of $R U N X 3(\mathrm{P}=0.006<0.01)$, BCL2L14 $(\mathrm{P}=0.001<0.01)$ and $C D C P 1(\mathrm{P}=0.032<0.05)$. By contrast, expression levels of FBLN1 $(\mathrm{P}=0.042<0.05)$, ITIH5 $(\mathrm{P}=0.021$ $<0.05)$ and DIRAS3 ( $\mathrm{P}=0.037<0.05)$ were significantly downregulated in TSCC tissue as compared with adjacent normal 

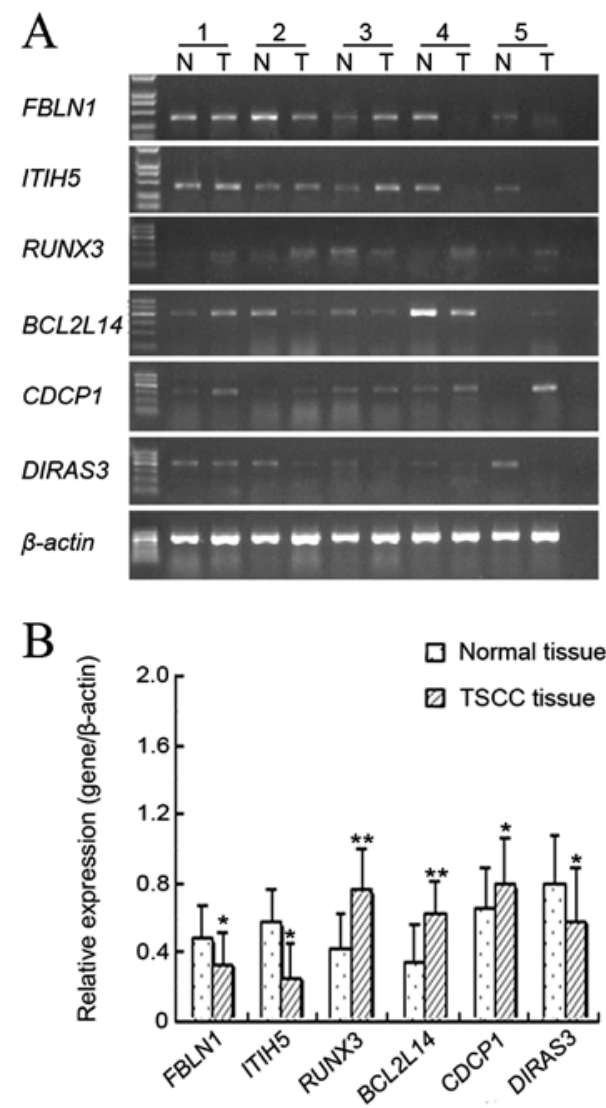

Figure 3. Gene expressions of six selected genes (FBLN1, ITIH5, RUNX3, $B C L 2 L 14, C D C P 1$ and DIRAS3) were detected by RT-PCR. (A) Representative bands of these six genes and $\beta$-actin are shown in paired adjacent normal $(\mathrm{N})$ and TSCC (T) tissues. (B) Relative mRNA expression levels of these six genes were assessed. All results were normalized to that of $\beta$-actin. Data are expressed as the means $\pm \mathrm{SD}(\mathrm{n}=20)$. ${ }^{*} \mathrm{P}<0.05$ vs. the adjacent normal control tissue; ${ }^{* *} \mathrm{P}<0.01$ vs. the adjacent normal control tissue.

tissue (Fig. 3). The gene expression levels of FBLNI, ITIH5 and RUNX3 in TSCC tissue were inversely correlated with the DNA methylation status.

\section{Discussion}

In the present study, a total of 9 paired samples from adjacent normal control and TSCC tissues were screened at the individual 28,226 CpG sites. The results demonstrated that 2,654 CpG sites were significantly different in methylation level: 1,269 sites, covering 330 genes, were hypermethylated in TSCC tissue and 1,385 sites, covering 321 genes, were hypermethylated in adjacent normal tissue. The microarray data could provide evidence and insights to further clarify the molecular mechanism in TSCC.

DNA methylation is the most common gene modification in eukaryotic cells. This epigenetic event has been studied extensively in the field of cancer research. In the past decade, several studies focused on the aberrant DNA methylation in various types of cancer, suggesting that the $\mathrm{CpG}$ island hypermethylation in gene promoter was closely related to inactivation of tumor suppressor gene or candidate tumor suppressor gene expression (12). Sardi et al (13) demonstrated that promoter hypomethylation resulted in the activation of oncogene expres- sion in human bladder cancer and local hypermethylation may be considered a potential mechanism for increasing genetic alterations in bladder cancer formation. Furthermore, aberrant DNA methylation can be detected before tumors are clinically evident. Kresty et al (14) showed that hypermethylation of the cell cycle-regulatory genes $p 16^{I N K 4 a}$ and $p 14^{A R F}$ were detected in 57.7 and $3.8 \%$ of patients, respectively, and the highest rates of $p 16^{I N K 4 a}$ hypermethylation occurred in lesions of the tongue and the floor of the mouth. The alterations of $p 16^{I N K 4 a}$ and p1 $4^{A R F}$ locus are frequent events preceding the development of oral cancer. As described by Palmisano et al (15), aberrant methylation of the $p 16$ and/or $\mathrm{O}^{6}$-methylguanine-DNA methyltransferase (MGMT) promoters can be detected in DNA from sputum in $100 \%$ of patients with lung squamous cell carcinoma up to three years before clinical diagnosis. In addition, Rosas et al (10) reported that aberrant methylation of at least one of these genes, $p 16^{C D K N 2 A}$, MGMT and death-associated protein kinase (DAP-K), were detected in $17(56 \%)$ of 30 head and neck primary tumors; 14 (47\%) of 30 at p16, 10 (33\%) of 30 at Dap-K and 7 (23\%) of 30 at MGMT. In $11(65 \%)$ of 17 methylated primary tumors, abnormally methylated DNA was detected in the matched saliva samples.

In order to verify our microarray data, we selected three genes (ITIH5, FBLNI and RUNX3), which have previously been reported in studies on aberrant DNA methylation in various types of cancer, and tested their levels of DNA methylation and mRNA expression in adjacent normal and TSCC tissues.

$F B L N 1$, fibulin 1, was identified as a tumor suppressor gene whose inactivation may contribute to carcinogenesis. FBLN1 plays a tumor suppressive role in gastric cancer (16) as well as in other types of cancer such as breast (17) and prostate cancer (18). Cheng et al (16) demonstrated that aberrant promoter hypermethylation resulted in downregulated expression of FBLNl in all gastric cancer cell lines and the primary gastric carcinoma tissues and was significantly restored after pharmacological demethylation. Kanda et al (19) reported that promoter hypermethylation of $F B L N 1$ was significantly associated with advanced stage hepatocellular carcinoma, multiple tumors and increased tumor size. The present study showed that $F B L N 1$ was hypermethylated and its mRNA level was significantly decreased in TSCC tissue compared with those in adjacent normal tissue. The exact molecular mechanism of how FBLN1 suppresses tumorigenesis remains unclear. Its expression could suppress cell motility, inhibit the phosphorylation of extracellular signal-regulated kinase and myosin light chain, and reduce the intracellular calcium level (20).

The inter- $\alpha$-trypsin inhibitors (ITIs) family constitutes a group of plasma proteins consisting of one light (bikunin) and two heavy chains (ITIHs). ITIH5 is a member of the ITIH gene family (21) and is a tumor suppressor gene. ITI plays a role in extracellular matrix stabilization and in the prevention of tumor metastasis (22). The studies of Veeck et al (21) and Himmelfarb et al (22) revealed that promoter methylation-mediated downregulation of ITIH5 expression was associated with unfavorable outcome in breast cancer patients. Hamm et al (23) reported that ITIH2, ITIH3, ITIH4 and ITIH5 were strongly downregulated in a variety of human solid tumors (breast, endometrium, ovary, cervix, stomach, small intestine, colon, rectum, lung, thyroid, prostate, kidney and pancreas). ITIH5 could be involved in the progression, 
invasion and metastasis of breast cancer, as its absence is associated with increased proliferation rates and a prognostic value indicating poor clinical outcome $(21,22)$. Data from our study indicated that aberrant ITIH5 promoter hypermethylation occurred in 14 out of 20 cases $(70 \%)$ in TSCC tissue. There were statistically significant differences in ITIH5 expression between TSCC and adjacent normal tissues.

$R U N X 3$, runt-related transcription factor 3, part of the runtrelated (RUNX) family, appears to be an important component of the transforming growth factor- $\beta$ (TGF- $\beta$ )-induced tumor suppression pathway. RUNX3 has a critical role in the regulation of cell proliferation and cell death by apoptosis, as well as in angiogenesis, cell adhesion and invasion (24). RUNX3 acts as a tumor suppressor gene in gastric cancer $(25,26)$. Aside from gastric cancer, it has been reported that downregulated expression of $R U N X 3$ is observed in bladder (27), gastric (28), liver (29-31), colorectal $(32,33)$ and lung (34) cancer. In these tumors, reduced expression of RUNX3 was frequently caused by $\mathrm{CpG}$ island hypermethylation. It was reported that $R U N X 3$ expression levels were upregulated in head and neck squamous cell carcinoma (35), basal cell carcinoma of skin (36) and ovarian cancer (37). RUNX3 may have an oncogenic role in HNSCC as well as in basal cell carcinoma of skin $(38,39)$. In addition, $R U N X 3$ expression was observed in the tongue and palate epithelium of mouse embryos and disappears in newborn and adult mice $(24,40)$. The results of this study are in accordance with these previous findings. RUNX3 was hypomethylated and its expression was upregulated in TSCC tissue. DNA hypermethylation of RUNX3 was observed in normal epithelial cells of the tongue, suggesting that RUNX3 may be silenced by methylation in normal oral mucosa. The exact molecular mechanism of $R U N X 3$ regulation in normal adult oral epithelium and TSCC remains unclear and requires further investigation.

Of the other three candidate genes, BCL2L14 and CDCPI were hypermethylated in adjacent normal tissue and DIRAS3 was hypermethylated in TSCC tissue. In the RT-PCR analysis, the expressions of $B C L 2 L 14$ and $C D C P 1$ were significantly upregulated in TSCC tissue compared to adjacent normal tissue, whereas the expression of DIRAS3 was markedly downregulated. Therefore, these findings indicate that the expressions of the three genes in TSCC tissues may be caused by the aberrant DNA methylation during the development of TSCC.

Apoptosis facilitator Bcl-2-like protein 14 (BCL2L14, also known as $\mathrm{Bcl}-\mathrm{G})$, is a protein encoded by the $B C L 2 L 14$ gene, and belongs to the Bcl-2 family. Bcl-2 family members act as anti- or pro-apoptotic regulators that are involved in a wide variety of cellular activities (41). The human $B c l-G$ gene encodes two proteins through alternative mRNA splicing, $B c l-G(\mathrm{~L})$ (long) and $B c l-G(\mathrm{~S})$ (short). $B c l-G(\mathrm{~L}) \mathrm{mRNA}$ is widely expressed in adult human tissues, whereas $B c l-G(\mathrm{~S})$ mRNA is found only in testis. Overexpression of this gene has been shown to induce apoptosis in cells. $B c l-G$ was downregulated in prostate (42) and breast cancer (43). However, in this study, BCL2L14 was observed to be hypomethylated with upregulated mRNA expression in TSCC tissue. CUB domain containing protein $(C D C P 1)$, a transmembrane protein with intracellular tyrosine residues which are phosphorylated upon activation, is assumed to be involved in proliferative activities and resistance to apoptosis of cancer cells (44). CDCPI is a novel stem cell marker that is expressed in several types of cancer. $C D C P 1$ mRNA highly overexpressed in human colon cancer (45) and lung adenocarcinoma (44). In the breast cancer samples of Ikeda et al (46), tumors with high-level CDCPI expression showed higher levels of proliferation. $C D C P 1$ may be involved in regulating the adhesion and motility of cancer cells (47).

In our study, $C D C P 1$ was shown to be hypermethylated in $\mathrm{CpG}$ site using microarray analysis but its expression was found to be upregulated using RT-PCR in TSCC tissue. DIRAS3 (also known as ARHI and NOEY2), GTP-binding protein Di-Ras3, is a novel imprinted tumor suppressor gene that encodes a small GTPase with $60 \%$ homology to Ras and Rap (48). Only the paternal allele of DIRAS3 is expressed due to maternal imprinting. DIRAS3 was absent or expressed at lower levels with allelic loss and promoter hypermethylation in ovarian, breast, and liver cancer as well as in other tumor tissues (49-51). DIRAS3 may play an important role physiologically in regulating cell growth through regulating expression of the cyclins and cyclin dependent kinase inhibitors (49). Our results showed that DIRAS3 gene expression was downregulated in TSCC tissue with hypomethylation status. The increased expression of BCL2L14 may be regulated by hypomethylation of its promoter region in TSCC tissue. However, the mechanism by which $C D C P 1$ expression was upregulated with DNA hypermethylation and DIRAS3 expression was downregulated with DNA hypomethylation in TSCC tissue compared with that in adjacent normal tissue, remains unclear.

In summary, genome-wide DNA methylation microarray was used to identify the methylated genes in TSCC. Distinctly different DNA methylation profiles were obtained from adjacent normal and TSCC tissues. Furthermore, we validated the methylation status of three candidate genes by MS-PCR and the mRNA expression level of six candidate genes by RT-PCR. These results are consistent with the microarray data. Our study may provide useful data for further investigation of TSCC biomarkers for diagnosis, treatment and prognosis. Future gene-specific investigations are required to explore the molecular mechanism of the tumorigenesis, development and progression of TSCC.

\section{References}

1. Markopoulos AK: Current aspects on oral squamous cell carcinoma. Open Dent J 6: 126-130, 2012.

2. Jemal A, Bray F, Center MM, Ferlay J, Ward E and Forman D: Global cancer statistics. CA Cancer J Clin 61: 69-90, 2011.

3. Choi S and Myers JN: Molecular pathogenesis of oral squamous cell carcinoma: implications for therapy. J Dent Res 87: 14-32, 2008.

4. Demokan S and Dalay N: Role of DNA methylation in head and neck cancer. Clin Epigenetics 2: 123-150, 2011.

5. González-Ramírez I, García-Cuellar C, Sánchez-Pérez Y and Granados-García M: DNA methylation in oral squamous cell carcinoma: molecular mechanisms and clinical implications. Oral Dis 17: 771-778, 2011.

6. Lister R, Pelizzola M, Dowen RH, Hawkins RD, Hon G, Tonti-Filippini J, Nery JR, Lee L, Ye Z, Ngo QM, Edsall L, Antosiewicz-Bourget J, Stewart R, Ruotti V, Millar AH, Thomson JA, Ren B and Ecker JR: Human DNA methylomes at base resolution show widespread epigenomic differences. Nature 462: 315-322, 2009.

7. Weber M, Davies JJ, Wittig D, Oakeley EJ, Haase M, Lam WL and Schubeler D: Chromosome-wide and promoter-specific analyses identify sites of differential DNA methylation in normal and transformed human cells. Nat Genet 37: 853-862, 2005. 
8. Bird A: DNA methylation patterns and epigenetic memory. Genes Dev 16: 6-21, 2002.

9. Carvalho RH, Haberle V, Hou J, van Gent T, Thongjuea S, van Ijcken W, Kockx C, Brouwer R, Rijkers E, Sieuwerts A, Foekens J, van Vroonhoven M, Aerts J, Grosveld F, Lenhard B and Philipsen S: Genome-wide DNA methylation profiling of non-small cell lung carcinomas. Epigenetics Chromatin 5: 9, 2012.

10. Rosas SL, Koch W, da Costa Carvalho MG, Wu L, Califano J, Westra W, Jen J and Sidransky D: Promoter hypermethylation patterns of p16, O6-methylguanine-DNAmethyltransferase, and death-associated protein kinase in tumors and saliva of head and neck cancer patients. Cancer Res 61: 939-942, 2001.

11. Jacinto FV, Ballestar E and Esteller M: Methyl-DNA immunoprecipitation (MeDIP): hunting down the DNA methylome. Biotechniques 44: 35-43, 2008.

12. Herman JG and Baylin SB: Gene silencing in cancer in association with promoter hypermethylation. N Engl J Med 349: 2042-2054, 2003

13. Sardi I, Dal Canto M, Bartoletti R and Montali E: Abnorma c-myc oncogene DNA methylation in human bladder cancer: possible role in tumor progression. Eur Urol 31: 224-230, 1997.

14. Kresty LA, Mallery SR, Knobloch TJ, Song H, Lloyd M, Casto BC and Weghorst CM: Alterations of p16(INK4a) and p14(ARF) in patients with severe oral epithelial dysplasia. Cancer Res 62: 5295-5300, 2002.

15. Palmisano WA, Divine KK, Saccomanno G, Gilliland FD, Baylin SB, Herman JG and Belinsky SA: Predicting lung cancer by detecting aberrant promoter methylation in sputum. Cancer Res 60: 5954-5958, 2000.

16. Cheng YY, Jin H, Liu X, Siu JM, Wong YP, Ng EK, Yu J, Leung WK, Sung JJ and Chan FK: Fibulin 1 is downregulated through promoter hypermethylation in gastric cancer. Br J Cancer 99: 2083-2087, 2008.

17. Pupa SM, Argraves WS, Forti S, Casalini P, Berno V, Agresti R, Aiello P, Invernizzi A, Baldassari P, Twal WO, Mortarini R, Anichini A and Menard S: Immunological and pathobiological roles of fibulin-1 in breast cancer. Oncogene 23: 2153-2160, 2004

18. Wlazlinski A, Engers R, Hoffmann MJ, Hader C, Jung V, Muller M and Schulz WA: Downregulation of several fibulin genes in prostate cancer. Prostate 67: 1770-1780, 2007.

19. Kanda M, Nomoto S, Okamura Y, Hayashi M, Hishida M, Fujii T, Nishikawa Y, Sugimoto H, Takeda S and Nakao A: Promoter hypermethylation of fibulin 1 gene is associated with tumor progression in hepatocellular carcinoma. Mol Carcinog 50: 571-579, 2011

20. Twal WO, Czirok A, Hegedus B, Knaak C, Chintalapudi MR Okagawa H, Sugi Y and Argraves WS: Fibulin-1 suppression of fibronectin-regulated cell adhesion and motility. J Cell Sci 114 4587-4598, 2001

21. Veeck J, Chorovicer M, Naami A, Breuer E, Zafrakas M, Bektas N, Dürst M, Kristiansen G, Wild PJ, Hartmann A, Knuechel R and Dahl E: The extracellular matrix protein ITIH5 is a novel prognostic marker in invasive node-negative breast cancer and its aberrant expression is caused by promoter hypermethylation. Oncogene 27: 865-876, 2008.

22. Himmelfarb M, Klopocki E, Grube S, Staub E, Klaman I Hinzmann B, Kristiansen G, Rosenthal A, Dürst M and Dahl E: ITIH5, a novel member of the inter-alpha-trypsin inhibitor heavy chain family is downregulated in breast cancer. Cancer Lett 204: 69-77, 2004

23. Hamm A, Veeck J, Bektas N, Wild PJ, Hartmann A, Heindrichs U, Kristiansen G, Werbowetski-Ogilvie T, Del Maestro R, Knuechel R and Dahl E: Frequent expression loss of Inter-alphatrypsin inhibitor heavy chain (ITIH) genes in multiple human solid tumors: a systematic expression analysis. BMC Cancer 8: 25, 2008.

24. Tsunematsu T, Kudo Y, Iizuka S, Ogawa I, Fujita T, Kurihara H, Abiko Y and Takata T: RUNX3 has an oncogenic role in head and neck cancer. PLoS One 4: e5892, 2009.

25. Li QL, Ito K, Sakakura C, Fukamachi H, Inoue K, Chi XZ, Lee KY, Nomura S, Lee CW, Han SB, Kim HM, Kim WJ, Yamamoto $\mathrm{H}$, Yamashita $\mathrm{N}$, Yano $\mathrm{T}$, Ikeda $\mathrm{T}$, Itohara $\mathrm{S}$, Inazawa J, Abe T, Hagiwara A, Yamagishi H, Ooe A, Kaneda A, Sugimura T, Ushijima T, Bae SC and Ito Y: Causal relationship between the loss of RUNX3 expression and gastric cancer. Cell 109: 113-124, 2002

26. Ito K, Liu Q, Salto-Tellez M, Yano T, Tada K, Ida H, Huang C, Shah N, Inoue M, Rajnakova A, Hiong KC, Peh BK, Han HC, Ito T, Teh M, Yeoh KG and Ito Y: RUNX3, a novel tumor suppressor, is frequently inactivated in gastric cancer by protein mislocalization. Cancer Res 65: 7743-7750, 2005.
27. Kim WJ, Kim EJ, Jeong P, Quan C, Kim J, Li QL, Yang JO, Ito $\mathrm{Y}$ and Bae SC: RUNX3 inactivation by point mutations and aberrant DNA methylation in bladder tumors. Cancer Res 65: 9347-9354, 2002

28. Chen W, Gao N, Shen Y and Cen JN: Hypermethylation downregulates Runx3 gene expression and its restoration suppresses gastric epithelial cell growth by inducing p27 and caspase 3 in human gastric cancer. J Gastroenterol Hepatol 25: 823-831, 2010.

29. Mori T, Nomoto S, Koshikawa K, Fujii T, Sakai M, Nishikawa Y, Inoue S, Takeda S, Kaneko T and Nakao A: Decreased expression and frequent allelic inactivation of the RUNX3 gene at 1p36 in human hepatocellular carcinoma. Liver Int 5: 380-388, 2005.

30. Shiraha H, Nishina S and Yamamoto K: Loss of runt-related transcription factor 3 causes development and progression of hepatocellular carcinoma. J Cell Biochem 112: 745-749, 2011.

31. Nishina S, Shiraha H, Nakanishi Y, Tanaka S, Matsubara M, Takaoka N, Uemura M, Horiguchi S, Kataoka J, Iwamuro M, Yagi T and Yamamoto K: Restored expression of the tumor suppressor gene RUNX3 reduces cancer stem cells in hepatocellular carcinoma by suppressing Jagged1-Notch signaling. Oncol Rep 26: 523-531, 2011.

32. Ku JL, Kang SB, Shin YK, Kang HC, Hong SH, Kim IJ, Shin JH, Han IO and Park JG: Promoter hypermethylation downregulates RUNX3 gene expression in colorectal cancer cell lines. Oncogene 23: 6736-6742, 2004.

33. Lee CW, Ito K and Ito Y: Role of RUNX3 in bone morphogenetic protein signaling in colorectal cancer. Cancer Res 70: 4243-4252, 2010.

34. Yanada M, Yaoi T, Shimada J, Sakakura C, Nishimura M, Ito K, Terauchi K, Nishiyama K, Itoh K and Fushiki S: Frequent hemizygous deletion at $1 \mathrm{p} 36$ and hypermethylation downregulate RUNX3 expression in human lung cancer cell lines. Oncol Rep 14: 817-822, 2005

35. Ginos MA, Page GP, Michalowicz BS, Patel KJ, Volker SE, Pambuccian SE, Ondrey FG, Adams GL and Gaffney PM: Identification of a gene expression signature associated with recurrent disease in squamous cell carcinoma of the head and neck. Cancer Res 64: 55-63, 2004.

36. Salto-Tellez M, Peh BK, Ito K, Tan SH, Chong PY, Han HC, Tada K, Ong WY, Soong R, Voon DC and Ito Y: RUNX3 protein is overexpressed in human basal cell carcinomas. Oncogene 25: 7646-7649, 2006

37. Lee CW, Chuang LS, Kimura S, Lai SK, Ong CW, Yan B, Salto-Tellez M, Choolani M and Ito Y: RUNX3 functions as an oncogene in ovarian cancer. Gynecol Oncol 122: 410-417, 2011.

38. Kudo Y, Tsunematsu T and Takata T: Oncogenic role of RUNX3 in head and neck cancer. J Cell Biochem 112: 387-393, 2011.

39. Ito K: RUNX3 in oncogenic and anti-oncogenic signaling in gastrointestinal cancers. J Cell Biochem 112: 1243-1249, 2011.

40. Lau QC, Raja E, Salto-Tellez M, Liu Q, Ito K, Inoue M, Putti TC, Loh M, Ko TK, Huang C, Bhalla KN, Zhu T, Ito Y and Sukumar S: RUNX3 is frequently inactivated by dual mechanisms of protein mislocalization and promoter hypermethylation in breast cancer. Cancer Res 66: 6512-6520, 2006.

41. Guo B, Godzik A and Reed JC: Bcl-G, a novel pro-apoptotic member of the Bcl-2 family. J Biol Chem 276: 2780-2785, 2000.

42. Pickard MR, Edwards SE, Cooper CS and Williams GT: Apoptosis regulators Fau and Bcl-G are down-regulated in prostate cancer. Prostate 70: 1513-1523, 2010.

43. Pickard MR, Green AR, Ellis IO, Caldas C, Hedge VL, MourtadaMaarabouni M and Williams GT: Dysregulated expression of Fau and MELK is associated with poor prognosis in breast cancer. Breast Cancer Res 11: R60, 2009.

44. Ikeda J, Oda T, Inoue M, Uekita T, Sakai R, Okumura M, Aozasa K and Morii E: Expression of CUB domain containing protein (CDCP1) is correlated with prognosis and survival of patients with adenocarcinoma of lung. Cancer Sci 100: 429-433, 2009.

45. Perry SE, Robinson P, Melcher A, Quirke P, Bühring HJ, Cook GP and Blair GE: Expression of the CUB domain containing protein 1 (CDCP1) gene in colorectal tumour cells. FEBS Lett 581: 1137-1142, 2007.

46. Ikeda JI, Morii E, Kimura H, Tomita Y, Takakuwa T, Hasegawa JI, Kim YK, Miyoshi Y, Noguchi S, Nishida T and Aozasa K Epigenetic regulation of the expression of the novel stem cell marker CDCP1 in cancer cells. J Pathol 210: 75-84, 2006.

47. Seidel J, Kunc K, Possinger K, Jehn C and Lüftner D: Effect of the tyrosine kinase inhibitor lapatinib on CUB-domain containing protein (CDCP1)-mediated breast cancer cell survival and migration. Biochem Biophys Res Commun 414: 226-232, 2011. 
48. Yuan J, Luo RZ, Fujii S, Wang L, Hu W, Andreeff M, Pan Y, Kadota M, Oshimura M, Sahin AA, Issa JP, Bast RC Jr and Yu Y: Aberrant methylation and silencing of ARHI, an imprinted tumor suppressor gene in which the function is lost in breast cancers. Cancer Res 63: 4174-4180, 2003.

49. Yu Y, Xu F, Peng H, Fang X, Zhao S, Li Y, Cuevas B, Kuo WL, Gray JW, Siciliano M, Mills GB and Bast RC Jr: NOEY2 (ARHI), an imprinted putative tumor suppressor gene in ovarian and breast carcinomas. Proc Natl Acad Sci USA 96: 214-219, 1999.
50. Luo RZ, Fang X, Marquez R, Liu SY, Mills GB, Liao WS, Yu Y and Bast RC: ARHI is a Ras-related small G-protein with a novel $\mathrm{N}$-terminal extension that inhibits growth of ovarian and breast cancers. Oncogene 22: 2897-2909, 2003.

51. Huang J, Lin Y, Li L, Qing D, Teng XM, Zhang YL, Hu X, Hu Y, Yang P and Han ZG: ARHI, as a novel suppressor of cell growth and downregulated in human hepatocellular carcinoma, could contribute to hepatocarcinogenesis. Mol Carcinog 48:130-140, 2009. 